\title{
VIGOR DETERMINATION OF OKRA SEEDS BY RESPIRATORY ACTIVITY
}

\author{
DETERMINAÇÃO DO VIGOR DE SEMENTES DE QUIABO PELA ATIVIDADE \\ RESPIRATÓRIA
}

\begin{abstract}
Moadir de Sousa LEITE ${ }^{1}$; Salvador Barros TORRES ${ }^{2}$; Rômulo Magno Oliveira de FREITAS ${ }^{3}$; Narjara Walessa NOGUEIRA ${ }^{2}$; Tiago de Sousa LEITE $^{4}$; Emanoela Pereira de PAIVA ${ }^{5}$

1. Eng. Agrônomo, Universidade Federal Rural do Semi-Árido, Mossoró, RN, Brasil. moadir@ outlook.com; 2. Professor, Doutor em Fitotecnia, Universidade Federal Rural do Semi-Árido, Mossoró, RN, Brasil; 3. Professor, Doutor em Fitotecnia, Instituto Federal de

Educação, Ciência e Tecnologia Baiano, Salvador, BA, Brasil; 4. Mestrando em Solos e Nutrição de Plantas, Escola Superior de Agricultura Luiz de Queiroz, ESALQ/USP, Piracicaba, SP, Brasil; 5. Doutor em Fitotecnia, Universidade Federal Rural do Semi-Árido, Mossoró, RN, Brasil.
\end{abstract}

\begin{abstract}
Seed companies increasingly need to obtain reliable results on seed vigor. Therefore, the objective was to verify the efficiency of the respiratory activity measurement, by the $\mathrm{CO}_{2}$ released, to classify the vigor of okra seed lots. For this, five seed lots of okra cv. "Santa Cruz 47" were used. In order to determine seed physiological quality, the following tests were performed: germination, seedling emergence, emergence speed index, shoot length, total dry matter, potassium leaching, electrical conductivity and respiratory activity. Mean values of germination and vigor were compared by Tukey's test. Respiratory activity was correlated with germination and other vigor tests by the Pearson's correlation. The results indicate that $\mathrm{CO}_{2}$ measurement is a promising method to identify vigor differences between okra seed lots.
\end{abstract}

KEYWORDS: Abelmoschus esculentus. $\mathrm{CO}_{2}$ measurement. Physiological quality.

\section{INTRODUCTION}

Okra (Abelmoschus esculentus (L.) Moench) is a vegetable adapted to tropical and subtropical climates, being cultivated in many parts of the world (SHARMA et al., 2014). Despite the economic importance of this species, research regarding its management is still scarce, especially in relation to seed handling.

The germination test is the most widely used to determine the physiological quality of seed lots. However, this test does not always reflect the results obtained in field conditions and its conduction can be time-consuming. Thus, it is necessary to develop rapid tests with results comparable to the emergence in the field. The germination test for okra seeds lasts for 21 days (BRASIL, 2009), which is a long period.

Several tests have been developed aiming at rapid and reliable results on seed quality. In this context, vigor tests stand out for their high correlation with field emergence. Among them, accelerated aging, potassium leaching and respiratory activity are some examples of low-cost and easily reproducible tests.

The respiratory activity test consists in measuring the amount of $\mathrm{CO}_{2}$ released from seeds during the respiration process, which results from the oxidation of organic substances in the cellular system after the start of the imbibition process. Thus, high respiratory rates are associated with vigorous seeds due to the oxidation of a large amount of reserve tissues present in their cells. This test is economic, rapid and easy to perform, as reported for Helianthus annuus L. (DODE et al., 2012), Glycine max L. (DODE et al., 2013) and Citrullus vulgaris Schrad. (OLIVEIRA et al., 2015). Therefore, the objective of this work was to verify the efficiency of $\mathrm{CO}_{2}$ measurement to determine vigor in okra seed lots.

\section{MATERIAL AND METHODS}

Five seed lots of okra cv. Santa Cruz 47, 2014/2015 crop year, were obtained from Brazilian seed companies. The water content of each seed lot, determined in a forced-air oven at $105 \pm 3{ }^{\circ} \mathrm{C}$ for 24 hours (BRASIL, 2009), ranged from 11.1 to $12.0 \%$ (wet basis). Then, the physiological quality of each seed lot was assessed as described below:

Germination test: four replications of 50 seeds per lot were sown in sand moistened with $60 \%$ of its water retention capacity, placed to germinate at $20-30{ }^{\circ} \mathrm{C}$ under a light regime of 12 hours at the highest temperature, and assessed at 21 days after sowing (BRASIL, 2009).

Seedling emergence, emergence speed index (ESI), shoot length and total dry matter: four replications of 50 seeds per lot were sown in $1.2 \mathrm{~m}$ wide, $0.15 \mathrm{~m} \mathrm{x} 0.05 \mathrm{~m}$ apart and $0.02 \mathrm{~m}$ deep beds. Seedling emergence was daily assessed up to 21 days after sowing in order to determine the ESI 
(MAGUIRE, 1962). After this period, emergence percentage, shoot length and total dry matter (determined in a forced-air oven at $60{ }^{\circ} \mathrm{C}$ until constant weight) were also determined.

Potassium leaching $(K L)$ and electrical conductivity $(E C)$ : seeds were weighed and then soaked in $75 \mathrm{~mL}$ of distilled water at $25{ }^{\circ} \mathrm{C}$ for 90 and 240 minutes for KL and EC, respectively. Then, the imbibition waters were subjected to readings, using a flame photometer for KL and a conductivity meter for EC (DIAS et al., 1998).

Respiratory activity (RA): the $\mathrm{CO}_{2}$ released from seeds was determined by the Pettenkofer method by adapting the methodology described by Oliveira et al. (2015) for watermelon seeds, using four replications of 10 grams of okra seeds per lot. Seeds from the different lots were first soaked in 50 $\mathrm{mL}$ of distilled water for 60 minutes. After this period, they were placed into the Pettenkofer apparatus for an additional period of 60 minutes and then respiration was measured (MENDES et al., 2009). Respiratory activity was calculated based on the following expression: N x D x 22 (Müller, 1964), where: $\mathrm{N}=$ normality of the acid used $(0.1 \mathrm{~N}$ $\mathrm{HCl}) ; \mathrm{D}=$ difference between the $\mathrm{HCl}$ volume used in the blank titration and the $\mathrm{HCl}$ volume used in the sample titration; $22=$ normality of $\mathrm{CO}_{2}$. Results were expressed as quantity of carbon dioxide released per gram of seed per hour $\left(\mu \mathrm{g} \mathrm{CO}_{2} \mathrm{~g} \mathrm{seed}^{-1}\right.$ $\left.h^{-1}\right)$.

A completely randomized experimental design with four replications was used. The data were subjected to ANOVA and means were compared by Tukey's test $(P \leq 0.05)$, using the SISVAR $^{\circledR}$ software (FERREIRA, 2011). Pearson's correlation $(P \leq 0.05)$ was used to assess the relationship between the vigor tests and seed respiratory activity.

\section{RESULTS AND DISCUSSION}

The germination test showed significant differences between the okra seed lots, with variations from 60 to $96 \%$. Lots 1 and 2 were superior to the others, although statistically similar to lot 3, and lot 5 had the lowest performance (Table 1). The field emergence had similar results, indicating lots 1 and 2 as the most vigorous ones, whereas lot 5 showed the lowest vigor level. The emergence test evaluates the maximum potential to produce normal seedlings in the field, often under unfavorable environmental conditions.

Table 1. Mean values ${ }^{1}$ of germination (G), seedling emergence (E), emergence speed index (ESI), shoot length (SL), seedling total dry mass (TDM), potassium leaching (KL), electrical conductivity (EC) and respiratory activity (RA), in lots of seeds of okra cv. Santa Cruz 47.

\begin{tabular}{ccccccccc}
\hline Lot & $\begin{array}{c}\mathrm{G} \\
(\%)\end{array}$ & $\begin{array}{c}\mathrm{E} \\
(\%)\end{array}$ & $\mathrm{ESI}$ & $\begin{array}{c}\mathrm{SL} \\
(\mathrm{cm})\end{array}$ & $\begin{array}{c}\mathrm{TDM} \\
(\mathrm{mg})\end{array}$ & $\begin{array}{c}\mathrm{KL} \\
(\mathrm{ppm})\end{array}$ & $\begin{array}{c}\mathrm{EC}(\mu \mathrm{S} \\
\left.\mathrm{cm}^{-1} \mathrm{~g}^{-1}\right)\end{array}$ & $\begin{array}{c}\mathrm{RA}\left(\mu \mathrm{g} \mathrm{CO} \mathrm{CO}_{2} \mathrm{~g}\right. \\
\left.\mathrm{seed}^{-1} \mathrm{~h}^{-1}\right)\end{array}$ \\
\hline 1 & $96 \mathrm{ab}$ & $94 \mathrm{a}$ & $7.4 \mathrm{~b}$ & $5.43 \mathrm{a}$ & $9.07 \mathrm{a}$ & $3.47 \mathrm{~d}$ & $14.95 \mathrm{a}$ & $5.57 \mathrm{a}$ \\
2 & $96 \mathrm{ab}$ & $94 \mathrm{a}$ & $8.5 \mathrm{a}$ & $4.61 \mathrm{ab}$ & $6.13 \mathrm{~b}$ & $3.78 \mathrm{~cd}$ & $16.33 \mathrm{ab}$ & $3.34 \mathrm{~b}$ \\
3 & $92 \mathrm{ab}$ & $90 \mathrm{a}$ & $7.4 \mathrm{~b}$ & $4.08 \mathrm{~b}$ & $5.16 \mathrm{bc}$ & $4.24 \mathrm{bc}$ & $18.87 \mathrm{~b}$ & $3.15 \mathrm{~b}$ \\
4 & $90 \mathrm{~b}$ & $82 \mathrm{~b}$ & $6.9 \mathrm{bc}$ & $4.15 \mathrm{~b}$ & $\begin{array}{c}4.57 \mathrm{~cd} \\
4.65 \mathrm{~b}\end{array}$ & $22.04 \mathrm{c}$ & $1.58 \mathrm{c}$ \\
5 & $60 \mathrm{c}$ & $76 \mathrm{~b}$ & $6.0 \mathrm{c}$ & $3.73 \mathrm{~b}$ & $3.86 \mathrm{~d}$ & $5.81 \mathrm{a}$ & $29.30 \mathrm{~d}$ & $0.78 \mathrm{c}$ \\
\hline $\mathrm{CV}(\%)$ & 4.2 & 5.6 & 7.2 & 11.8 & 8.5 & 6.3 & 6.4 & 18.7 \\
\hline
\end{tabular}

${ }^{1}$ Means followed by the same letter in the column do not differ by Tukey test $(P \leq 0.05)$.

Although seedlings obtained from lot 2 emerged with greater speed, those from lot 1 showed a higher average shoot length, but this variable did not differ statistically between these lots. A larger translocation of seed reserves to the embryonic axis growth leads to seedlings with increased shoot length, which characterizes a greater seedling vigor, as emphasized by Oliveira et al. (2015).

Similarly to what was observed for shoot length, the total dry matter pointed lot 1 as having the best physiological quality and lot 5 as being the least vigorous, with the lowest content of dry matter in comparison to the other lots. According to Dode et al. (2012), for a given species, seedlings with greater shoot length and fresh and dry matter suggest that the seeds from which they were originated had better physiological quality. Therefore, these seedlings are considered as more vigorous, as it was verified for those obtained from lot 1 .

The data regarding electrical conductivity and potassium leaching indicated lot 1 as having the best physiological quality and lot 5 as the one with the worst performance, which gives support to the results obtained in the other tests. High conductivity values are related to a reduction in membrane integrity, directly undermining seedling development as less vigorous seeds have poorly structured membranes and damaged cells, which is 
associated with the process of seed deterioration (OLIVEIRA et al., 2015). Similarly, seed lots of greater physiological quality undergo less leaching of potassium (ALVES; SÁ, 2010).

It was possible to rank the respiratory activity into high, medium and low, confirming lots
1 and 5 as the most and least vigorous, respectively. This test was positively correlated with seedling emergence, shoot length and total dry matter, and inversely proportional to potassium leaching and electrical conductivity tests (Table 2 ).

Table 2. Coefficient of simple linear correlation between respiratory activity (RA) and germination (G), seedling emergence (E), emergence speed index (ESI), shoot length (SL), seedling total dry mass (TDM), potassium leaching (KL) and electric conductivity (EC) of okra seeds, cv. Santa Cruz 47".

\begin{tabular}{llllllll}
\hline \multicolumn{7}{c}{ Coefficient of correlation } \\
\hline Tests & G & E & ESI & SL & TDM & KL & EC \\
\hline RA & $0.77^{\text {ns }}$ & $0.91^{*}$ & $0.59^{\text {ns }}$ & $0.93^{*}$ & $0.97^{* *}$ & $-0.91^{*}$ & $-0.90^{*}$ \\
\hline
\end{tabular}
Significant $(P \leq 0.05) ;{ }^{* *}$ Significant $(P \leq 0.01) ;{ }^{\text {ns }}$ Not significant.

The greater the release of leachate to the soaking solution, the smaller the amount of $\mathrm{CO}_{2}$ released during cellular respiration and, consequently, the lower the seed vigor. According to Marcos Filho (2015), the reduction in germination speed is not the first event in the process of seed deterioration. Consequently, emergence speed index showed low sensitivity to identify small vigor differences. Thus, similarly to the germination test, it did not correlate significantly with respiratory activity.

In lots of low physiological quality, such as lot 5 , there is a reduction in the membrane reconstruction speed during imbibition, resulting in lower respiratory rates due to the lower number and/or efficiency of mitochondria (OLIVEIRA et al., 2015). Thus, this will result in less vigorous seedlings, as evidenced by the correlations between respiratory activity and the other vigor tests performed. In contrast, viable embryos have intact mitochondria, whose respiratory activity increases with the start of imbibition, which makes these organelles more efficient in the production of adenosine triphosphate (ATP). Therefore, a greater oxygen consumption is demanded, which consequently increases the production of carbon dioxide (BEWLEY; BLACK, 1994). In this context, vigorous seed lots have a higher respiratory rate, as evidenced in seeds from lot 1 .

\section{CONCLUSION}

The measurement of respiratory activity by $\mathrm{CO}_{2}$ released is a promising test to identify vigor differences between seed lots of okra cv. Santa Cruz 47.

RESUMO: As empresas produtoras de sementes necessitam cada vez mais da obtenção de resultados confiáveis quanto ao vigor da semente. Nesse sentido, objetivou-se verificar a eficiência da medição da atividade respiratória, através da emissão de $\mathrm{CO}_{2}$, para classificação do vigor de lotes de sementes de quiabo. Para isso, utilizaram-se cinco lotes de sementes de quiabo cv. "Santa Cruz 47". Para determinação da qualidade fisiológica das sementes, foram realizados os seguintes testes: germinação, emergência, índice de velocidade de emergência, comprimento da parte aérea, matéria seca total, lixiviação de potássio, condutividade elétrica e atividade respiratória. As médias de germinação e vigor foram comparadas pelo teste de Tukey. O teste de atividade respiratória foi correlacionado com a germinação e demais testes de vigor através da correlação de Pearson. A medição do $\mathrm{CO}_{2}$ constitui-se em um método promissor para identificar diferenças de vigor em lotes de sementes de quiabo.

PALAVRAS-CHAVE: Abelmoschus esculentus. Medição de $\mathrm{CO}_{2}$. Qualidade fisiológica.

\section{REFERENCES}

ALVES, C. Z; SÁ, M. E. Avaliação do vigor de sementes de rúcula pelo teste de lixiviação de potássio.

Revista Brasileira de Sementes, Londrina, v. 32, n. 2, p. 108-116, 2010.

http://www.scielo.br/pdf/rbs/v32n2/v32n2a13.pdf

BEWLEY, J. D; BLACK, M. Seeds: physiology of development and germination. 2.ed. New York: Plenum, 1994. 445p. https://doi.org/10.1007/978-1-4899-1002-8 
BRASIL. Ministério da Agricultura, Pecuária e Abastecimento. Regras para análise de sementes. Ministério da Agricultura, Pecuária e Abastecimento. Secretaria de Defesa Agropecuária. Brasília: MAPA/ACS, 2009. 395p.

DIAS, D. C. F. S; VIEIRA, A. N; BHÉRING, M. C. Condutividade elétrica e lixiviação de potássio para avaliação do vigor de sementes de hortaliças: feijão-de-vagem e quiabo. Revista Brasileira de Sementes, Londrina, v. 20, n. 2, p. 170-175, 1998. http://www.abrates.org.br/revista/artigos/1998/v20n2/artigo28.pdf

DODE, J. S; MENEGHELLO, G. E; MORAES, D. M; PESKE, S. T. Teste de respiração para avaliar a qualidade fisiológica de sementes de girassol. Revista Brasileira de Sementes, Londrina, v. 34, n. 4, p. 686691, 2012. http://www.scielo.br/pdf/rbs/v34n4/21.pdf

DODE, J. S; MENEGHELLO, G. E; TIMM, F. C; MORAES, D. M; PESKE, S. T. Teste de respiração em sementes de soja para avaliação da qualidade fisiológica. Ciência Rural, Santa Maria, v. 43, n. 2, p. 193-198, 2013. http://www.scielo.br/pdf/cr/v43n2/a3613cr5997.pdf

FERREIRA, D. F. Sisvar: a computer statistical analysis system. Ciência Agrotecnologia, Lavras, v. 35, n. 6, p. 1039-1042, 2011. http://www.scielo.br/pdf/cagro/v35n6/a01v35n6

MAGUIRE, J. D. Speed of germination: aid in selection and evaluation for seedling emergence and vigour. Crop Science, Madison, v. 2, n. 2, p. 176-177, 1962.

https://dl.sciencesocieties.org/publications/cs/abstracts/2/2/CS0020020176

MARCOS-FILHO, J. Seed vigor testing: an overview of the past, present and future perspective. Scientia Agricola, Piracicaba, v. 72, n. 4, p. 363-374, 2015. http://www.revistas.usp.br/sa/article/view/100211

MENDES, C. R; MORAES, D. M; LIMA, M. G. S; LOPES, N. F. Respiratory activity for the differentiation of vigor on soybean seeds lots. Revista Brasileira de Sementes, Londrina, v. 31, n. 2, p. 171-176, 2009. http://www.scielo.br/pdf/rbs/v31n2/v31n2a20.pdf

MÜLLER, L. E. Manual de laboratório de fisiologia vegetal. 1.ed. Turrialba: Instituto Interamericano de Ciências Agrícolas de la O.E.A., 1964. 165p.

OLIVEIRA, L. M; CAVALHEIRO, V. B.D; MORAES, D. M; TILMANN, M. A. A; SCHUCH, L. O. B. Medição do $\mathrm{CO}_{2}$ como método alternativo para a diferenciação do vigor de lotes de sementes de melancia. Ciência Rural, Santa Maria, v. 45, n. 4, p. 606-611, 2015. http://www.scielo.br/pdf/cr/v45n4/0103-8478-cr-0000-cr-20130594.pdf

SHARMA, A. D; RATHOREB, S. V.S.; SRINIVASANA, K; TYAGI, R. K. Comparison of various seed priming methods for seed germination, seedling vigour and fruit yield in okra (Abelmoschus esculentus $\mathrm{L}$. Moench). Scientia Horticulturae, v. 165, p.75-81, jan. 2014. https://doi.org/10.1016/j.scienta.2013.10.044 http://www.sciencedirect.com/science/article/pii/S0304423813005700 